to the hippocampus. Moreover, Goldby reproduces what appears to be a very convincing photomicrograph of a sagittal section of the brain of a rat which illustrates the precommissural hippocampal rudiment extending dorsally to the genu of the corpus callosum to become directly continuous with the indusium. Uther observations of Goldby on the brain of a bat, Eptesicus, in which the disturbing influence of a subsplenial flexure is absent, also indicate that (as Elliot Smith maintained in his classical studies) the corpus callosum of placental mammals really does lie morphologically ventral to the hippocampus or its vestiges.

It remains to be seen whether Dr. Abbie's theory will find acceptance with other comparative neurologists. It may be suggested, in any event, that it will require to be supported by embryological evidence before it is found to be acceptable.

\footnotetext{
1 "The Origin of the Corpus Callosum", J. Comp. Neurol., 70, 9 (1939) 2 "The Ancestors of the Eutheria", NATURE, 144, 523 (1939). " "On the Relative Position of the Hippocampus and the Corpus Callosum in Placental Mammals". J. Anat., 74, 227 (1940).
}

\title{
A ROMAN TOWN IN EAST YORKSHIRE
}

$\mathrm{T}$ HE completion of five seasons excavation in the Bozzes Field, at Brough, East Yorkshire, affords an opportunity for a summary of the results of the investigation. Although further excavation may necessitate modification of detail, it is considered that the examination of this Roman site has gone sufficiently far to secure the main outlines and conclusions as to its history which have been attempted by Mr. Philip Corder and Rev. Thomas Romans ("Excavations at the Roman Town at Brough, 1937", Hull Museum Publications, No. 206; 1939).

Although the site lies within the northern military area and is on a route that was of great strategic importance during the early wars against the Brigantes, its occupation throughout its history, except for a brief period in the first century, was of a civil character. The Parisii of the wolds, in whose territory it was situated, were village dwellers, and no hill-top fort or town is known in the part of Yorkshire which they inhabited. Petuaria, as it is now known the town was called, eventually became the tribal capital and a walled town with Romanized institutions, but in size it never exceeded twelve acres.

Little is known of the life of the Parisii before the Roman conquest, but a settlement has recently come to light at North Ferriby on the north bank of the Humber, placed conveniently on the pre-Roman route across the Humber and at the same time well situated for overseas trade with the Belgae of the Continent, for which evidence is afforded by Samian ware, terra nigrea and butt beakers found side by side with native vessels. Occupation, apparently, closes in the middle of the first century, at about the time of, or soon after, the establishment of the Ninth Legion at Lincoln in A.D. 47 and the construction of Ermine Street. North Ferriby was then abandoned and the inhabitants, moving about three miles up the river, founded Petuaria at the point where Ermine Street crosses the Humber.

The phases of occupation may be summarized in brief as follows : The original settlement, little more than a kraal of native huts, without defences or regular plan, was swept away and the sites of the huts levelled to make way for the first Roman town in the opening years of the second century. This town also was without defences. For a period after A.D. 71 a semi-permanent military base camp existed north of the settlement, which was abandoned after the construction of a great permanent fort farther north at Malton. In the reign of Trajan at the turn of the century grandiose plans were initiated for rebuilding the whole town in stone in Roman fashion.
Massive foundations were laid and good roads made for the first time. These plans were never carried to completion.

The reason for the interruption, which appears also at Malton, is unknown. Early in the reign of Hadrian, building was resumed, attention being directed first to the defences, for which the earlier plan had made no provision. These defences are contemporary with Hadrian's Wall. The earliest buildings in stone within the town now appear, but their construction is poor and suggests haste. Thirty or forty years later much building activity is evident. In the reign of Antoninus Pius the defences, in which ramparts of turf had been employed, were entirely reconstructed in stone, a massive wall revetment being constructed in front of a rampart of red clay incorporating the earlier turf bank. The Antonine period marks the hey-day of Petuaria, and small though it was, it must have been a centre of Roman culture.

Throughout the third century town life in Britain declined, while large estates and farms flourished. Petuaria shared the general fate. No complete building can be ascribed to this century, though coins and pottery attest a continued occupation. It shared also, however, in the attempt to revive town life in the fourth century under Constantius Chlorus. The town walls received massive rectangular towers, 25 feet wide and 10 feet deep. Within the town old buildings were reconditioned and new ones constructed. The attempt to put new life into the town failed here as elsewhere and beyond a few minor alterations to existing structures no building within the town can be attributed to a later date than the beginning of the fourth century. The coin list dwindles and ends with single coins of Gratian and Magnus Maximus, while late fourth century pottery of the period of the coastal signal stations occurs only sparsely. It is impossible to resist the conclusion that the life of Petuaria had already shrunk to insignificance at the time when the farms of the wolds were still prosperous.

Evidence of the status of Petuaria is afforded by an inscribed stone set up in the reign of Antoninus Pius by M. Ulpius Januarius, aedile of the vicus, to commemorate work done at his own expense in connexion with a theatre. Normally the vicus was unimportant and the business of its council parochial. The existence of an aedile at Petuaria implies the dignity of a self-governing civitas with full jurisdiction over all the vici in its territory. This in conjunction with other evidence would go to show that Petuaria had now become the seat of cantonal authority. 